\title{
Signal transduction in Plasmodium-Red Blood Cells interactions and in cytoadherence
}

\author{
LAURA N. CRUZ ${ }^{1 *}$, YANG WU ${ }^{2 *}$, ALISTER G. CRAIG ${ }^{2}$ and CÉLIA R.S. GARCIA ${ }^{1}$ \\ ${ }^{1}$ Departamento de Fisiologia, Instituto de Biociências, Universidade de São Paulo, \\ Rua do Matão, travessa 14, n 321, 05508-900 São Paulo, SP, Brasil \\ ${ }^{2}$ Liverpool School of Tropical Medicine, Pembroke Place, Liverpool L3 5QA, Liverpool, UK
}

Manuscript received on November 14, 2011; accepted for publication on March 9, 2012

\begin{abstract}
Malaria is responsible for more than 1.5 million deaths each year, especially among children (Snow et al. 2005). Despite of the severity of malaria situation and great effort to the development of new drug targets (Yuan et al. 2011) there is still a relative low investment toward antimalarial drugs. Briefly there are targets classes of antimalarial drugs currently being tested including: kinases, proteases, ion channel of GPCR, nuclear receptor, among others (Gamo et al. 2010). Here we review malaria signal transduction pathways in Red Blood Cells (RBC) as well as infected RBCs and endothelial cells interactions, namely cytoadherence. The last process is thought to play an important role in the pathogenesis of severe malaria. The molecules displayed on the surface of both infected erythrocytes (IE) and vascular endothelial cells (EC) exert themselves as important mediators in cytoadherence, in that they not only induce structural and metabolic changes on both sides, but also trigger multiple signal transduction processes, leading to alteration of gene expression, with the balance between positive and negative regulation determining endothelial pathology during a malaria infection.
\end{abstract}

Key words: cytoadherence, erythrocyte, malaria, Plasmodium, signal transduction.

\section{INTRODUCTION}

Plasmodium parasites are able to sense host signals to modulate their function through a complex cellular machinery and membrane receptors (Hotta et al. 2000, Garcia et al. 2008, Koyama et al. 2009). Moreover $\mathrm{Ca}^{2+}$ signalling pathways in Plasmodium are crucial for parasite development thus molecules involved in these pathways can be promising antimalarial targets (McCallum-Deighton and Holder 1992, Hotta et al. 2000, Gazarini and Garcia 2004).

\footnotetext{
*These authors contributed equally to this review Correspondence to: Célia R.S. Garcia E-mail: cgarcia@usp.br
}

Interestingly, cytoadherence of infected erythrocyte is also regulated by host signalling responses and Plasmodium falciparum proteins such as PfEMP1 binding to CD36 or ICAM-1 host receptors can modulate dendridic cells, monoycytes, endothelium and $\mathrm{T}$ cells (Urban et al. 1999, Ndungu et al. 2006, Chakravorty et al. 2008, Langhorne et al. 2008) in addition to soluble mediators. Inhibitors of TNF (tumor necrosis factor) also reduced infected erythrocyte cytoadherence (Wassmer et al. 2006b, Chakravorty et al. 2008) and comparison of murine malaria strains indicates that host immunological responses such as TNF 
secretion, $\mathrm{T}$ cell activation and pro-inflammatory cytokine activation lead to differences in parasite growth or death (Wykes and Good 2008). Based on this we have reviewed the importance of $\mathrm{Ca}^{2+}$ modulated targets as antimalarial drugs.

Host Signals and Modulation of Plasmodium Cell Cycle

Signal transduction regulation inside Plasmodium has been shown as a major mechanism controlling parasite development. Plasmodium is able to sense host signals to modulate its function through a complex cellular machinery and membrane receptors (Garcia et al. 2008, Koyama et al. 2009). Moreover $\mathrm{Ca}^{2+}$ signalling pathways in Plasmodium are crucial for parasite development. The ion can be released from internal stores or from the extracellular medium (Gazarini and Garcia 2004, Hotta et al. 2000, Mccallum-Deighton and Holder 1992). During the intraerytrocytic development the ion is involved in $P$. falciparum and $P$. chabaudi synchronization through the hormone melatonin and its precursors $\mathrm{N}$-acetylserotonin, tryptamine, serotonin and $\mathrm{N}(1)$-acetyl-N(2)formyl-5-methoxykynuramine (AFMK) (Beraldo et al. 2005, 2007, Budu et al. 2007, Hotta et al. 2000). Interestingly, the presence of the hormone melatonin induces release of intracellular $\mathrm{Ca}^{2+}$ which can be blocked by PLC inhibitor or melatonin antagonist. Recently, it has been shown by caged-IP3 and confocal analysis that melatonin elicited intracellular $\mathrm{Ca}^{2+}$ increase though IP3PLC pathway in P. falciparum trophozoite (Alves et al. 2010). Measurements of intracellular cAMP and protein kinase A (PKA) activity also showed that melatonin triggers cAMP production and PKA activation (Gazarini et al. 2011).

Differences among developmentalstages within Plasmodium falciparum signalling was reported and melatonin modulation was not observed in ring or schizont stages (Alves et al. 2010). Furthermore melatonin did not elicit calcium rise in the rodent parasites $P$. berghei and P. yoelii (Bagnaresi et al. 2009) once those are asynchronous parasites with a distinct profile of proteolysis modulation (Cruz et al. 2011, Farias et al. 2005).

Another important extracellular signal that modulates Plasmodium-RBC interaction is ATP which has been described to induce increase of intracellular $\mathrm{Ca}^{2+}$ in $P$. falciparum, $P$. berghei and $P$. yoelii thus suggesting the presence of a putative purinoreceptor in the parasite (Levano-Garcia et al. 2011, Cruz et al. in press). Erythrocytes infected by Plasmodium, as damaged cells, can increase ATP level of the medium (Akkaya et al. 2009) and $P$. falciparum was unable to infect erythrocytes after ATP depletion (Rangachari et al. 1986). Moreover, the ATP receptor blocker suramin binds to merozoite surface proteins-1 (MSP1) inhibiting its cleavage and erythrocyte invasion by Plasmodium falciparum merozoites (Fleck et al. 2003). ATP is also thought to be involved in host induced inflammation which is followed by malaria infection (Clark et al. 2006).

Among the host signalling molecules Xanthurenic acid (XA), produced by the mosquito, triggers differentiation of male/female gametes, although it is not yet identified the parasite receptor for XA (Muhia et al. 2001, Ward et al. 2004). Recently gametocyte exflagellation, DNA synthesis and $\mathrm{Ca}^{2+}$ mobilization was shown to be inhibited by U73122 indicating the importance of phosphoinositide-specific phospolipase $\mathrm{C}$ pathway during gametocyte activation (Raabe et al. 2011).

Cyclic GMP-dependent protein kinase (PKG) might be involved in gametogenesis by cyclic GMP once exflagellation and rounding up of microgametocytes are induced in the presence of zaprinast (a specific inhibitor of cGMP-PDE). The presence of an upstream $\mathrm{Ca}^{2+}$ pathway activated by cyclic GMP-dependent protein kinase (PKG) to initiate gametogenesis (Mcrobert et al. 2008) is suggested. Regarding asexual stages, PKG is involved in the progression of $P$. falciparum 
schizogony as in the presence of a PfPKG inhibitor formation of rings is reduced and electron micrographs showed alteration in schizonts morphology (Taylor et al. 2010).

During the Plasmodium cell cycle, $\mathrm{Ca}^{2+}$ is also involved in invasion of hepatocyte by triggering microneme secretion (Ono et al. 2008, Vaid et al. 2008), phosphorylation of merozoyte motility components via PfPKB induced by calmodulin (Vaid et al. 2008), translocation of microneme proteins (e.g. EBA175), apical membrane antigen-1 (AMA1) to merozoite surface (Singh et al. 2010) and to induce secretion of rhoptry protein to the merozoite surface.

Following merozoite attachment at the erythrocyte membrane there is a decrease in cytosolic $\mathrm{Ca}^{2+}$ level, similarly described in $T$. gondii tachyzoites (Singh et al. 2010, Lovett and Sibley 2003). This signalling mechanism might be a feedback to reduce further microneme protein secretion to merozoite surface (Singh et al. 2010).

$\mathrm{Ca}^{2+}$ Modulated Antimalarial TARgets

The calcium-dependent protein kinases (CDPKs) are only found in plants and protists (Harper and Harmon 2005) and interestingly the Plasmodium has at least 5 CDPKs and gene knock out studies pointed out the importance of these kinases (Doerig et al. 2010, Hall et al. 2005, Ward et al. 2004). Disruption strategies of $P$. falciparum PfCDPK1 were not successful whereas PfCDPK1 inhibitory assays blocked the cell cycle at shizont stage (Kato et al. 2008). Reverse genetics studies carried out in Plasmodium berghei CDPK reported that PbCDPK3 is involved in ookinete motility in the mosquito midgut which requires intracellular $\mathrm{Ca}^{2+}$ mobilization (Ishino et al. 2006). PbCDPK4 is calcium dependent and is involved in male gametocyte exflagellation induced by XA in the mosquito gut (Billker et al. 2004, Ward et al. 2004). Mutant PbCDPK6 sporozoites showed a reduced invasion phenotype probably due to contact with the host heparin sulfate proteoglycans (HSPGs) and cAMP-dependent protein kinase (PKA) activation (Coppi et al. 2007).

P. falciparum cAMP-dependent protein kinase (PfPKA) activity is expressed at the sexual and asexual stages of the parasite (Wurtz et al. 2011). PfPKA is involved in $\mathrm{Ca}^{2+}$ signalling pathways (Beraldo et al. 2005, Wurtz et al. 2009), motility of sporozoites, apical exocytosis, cell invasion (Kebaier and Vanderberg 2010, Ono et al. 2008) and regulation of mitochondrial protein traffic (Wurtz et al. 2009, De Rasmo et al. 2008).

The protein kinase B-like enzyme (PKB) in mammalian cells, has been shown to be involved in regulation of transcription factors, apoptosis and glycogen pathways (Alessi et al. 1996, Andjelkovic et al. 1997, Vanhaesebroeck and Alessi 2000). Interestingly in P. falciparum the protein kinase B-like (PfPKB) does not contain the $\mathrm{PH}$ (phosphoinositide interaction) homology domain and its activity is regulated by $\mathrm{Ca}^{2+}$ / $\mathrm{CaM}$ autophosphorylation and $\mathrm{N}$-terminal region modulation (Vaid and Sharma 2006, Ward et al. 2004). PfPKB is present at the cytoplasm of schizonts/trophozoites and at the apical end of merozoites (Kumar et al. 2004). Blocking the function of the upstream activators of this pathway resulted in impaired invasion. PfPKB inhibitors dramatically reduced the ability of the parasite to invade erythrocytes and the work of PfPKB was associated with actin-myosin motor and phosphorylates PfGAP45 (glideosome-associated protein 45) (Vaid et al. 2008). PfPI3K, a Phosphatidyl-inositol-3kinase in P. falciparum was reported as a second messenger involved in endocytosis and trafficking of haemoglobin. Inhibition of PfPI3K resulted in attenuated hemoglobin digestion and the inhibition of parasite growth (Vaid et al. 2010).

It is noteworthy that protein kinase C (PKC) activity is not present in the $P$. falciparum genome database (Carlton et al. 2008) although it has been 
suggested that in plants CDPK may function as PKC (Satterlee and Sussman 1998). Interestingly, the receptor for activated $\mathrm{C}$ kinase 1 (RACK1) is a protein involved in $\mathrm{Ca}^{2+}$ signalling by recruiting protein kinase $\mathrm{C}(\mathrm{PKC})$ isoforms, InsP3 receptors, proteins $\mathrm{G}$ and others to its substrates (Schechtman and Mochly-Rosen 2001, Chen et al. 2004, Patterson et al. 2004). In mammalian cells, RACK1 has been shown to be involved in the circadian clock through interaction with PKC alpha and inhibition of CLOCK-BMAL1 activity (Robles et al. 2010). Plasmodium falciparum expresses a PfRACK (Madeira et al. 2003). Moreover functional genomics approaches show that PfRACK modulates $\mathrm{Ca}^{2+}$ signalling by inhibiting InsP3 evoked $\mathrm{Ca}^{2+}$ release in mammalian cells (Sartorello et al. 2009). PfRACK has also been identified in Maurer's clefts indicating a role for the protein in signalling pathways within host cells (Garcia et al. 2008, Lanzer et al. 2006).

Another important $\mathrm{Ca}^{2+}$ modulated targets are the proteases. During the intraerytrocytic development the parasite alters the RBC plasma membrane and a variety of proteins are proteolyticaly processed (Wu et al. 2003, Garcia et al. 2008, Maier et al. 2009, Cruz et al. 2011, in press). Proteases have been shown to mediate the rupture of merozoites from RBC (Arastu-Kapur et al. 2008, Blackman 2008), as well as protein trafficking by processing of the PEXEL motif in the endoplasmatic reticulum (Boddey et al. 2010, Russo et al. 2010) and degradation of the erythrocyte cytoskeletal proteins through the calcium activated host protein calpain 1 (Chandramohanadas et al. 2009).

Interestingly, calpains are cysteine proteases activated by calcium present in the host and the parasite. Phylogenetic analyses showed that many Plasmodium species has a calpain with homology on the N-terminal domain not found in the mammalian homology calpain (Russo et al. 2009, $\mathrm{Wu}$ et al. 2003). Interestingly the host calpain is involved in cytoskeletal remodeling (Goll et al.
2003) and Plasmodium calpain-1 function has been related to parasite egress from erythrocyte whereas cysteine protease inhibitor blocked erythrocyte membrane disruption (Chandramohanadas et al. 2009, Roiko and Carruthers 2009). Efforts to knockout the Plasmodium falciparum calpain was not successful, indicating the importance of this protease (Russo et al. 2009).

To illustrate Plasmodium intraerythrocitic calcium signalling a putative model is shown in figure 1 .

\section{PARASITE LIGANDS AND ENDOTHELIAL RECEPTORS}

The most notable parasite ligand for cytoadherence is $P$. falciparum erythrocyte membrane protein 1 (PfEMP1), an antigenically diverse protein family that is expressed on the surface of knoblike structures of mature IEs (Leech et al. 1984). PfEMP-1 varies within and between genetically identical parasite clones resulting in changes in their avidity for endothelial cell receptors. Other potential parasite ligands include Rifin, Stevor, modified Band 3 and Surfin that have been reviewed elsewhere (Rowe et al. 2009). Several endothelial surface receptors have been identified and characterised, including CD36 (Barnwell et al. 1989, Ockenhouse et al. 1989) Thrombospondin (TSP) (Roberts et al. 1985), VCAM, E-selectin (Ockenhouse et al. 1992), P-selectin (Ho et al. 1998), gC1qR (Biswas et al. 2007) and Intercellular adhesion molecule-1 (ICAM-1) (Berendt et al. 1989). Both CD36 and ICAM-1 have been identified as receptors commonly mediating cytoadherence of patient derived Pf-IE (Newbold et al. 1997) and their effects in trigging and regulating signal transduction events have been well characterised; in this section we will review recent advances in cytoadherence and signalling which is illustrated by figure 2 showing the interface of Plasmodium falciparum infected erythrocyte (PRBC) and endothelial cell (EC). 


\section{ICAM-1 MEDIATED ADHESION AND SIGNALLING}

ICAM-1 is constitutively present on ECs but its expression is highly increased by pro-inflammatory cytokines such as interleukin-1 (IL-1), tumour necrosis factor (TNF) (Pober 2002). The stimulation of human vascular endothelial cells with Pf-IE resulted in the non-transient up-regulation of ICAM-1 expression on human ECs. The induction was independent of TNF (Esslinger et al. 1994) indicating that TNF-independent mechanisms (in addition to TNF-dependent) might exist in the pathogenesis of cerebral malaria (CM). The ability of Pf-IE to directly modulate EC depends on the avidity of IE for the receptors on host endothelium and is proportional to the level of activation of the signalling pathways, which usually requires direct physical contact (Chakravorty et al. 2007, Gray et al. 2003, Viebig et al. 2005). ICAM-1 signalling occurs by receptor multimerization that is triggered when ligands bind in an 'outside-in' fashion. The ICAM-1 promoter contains several potential transcription factor binding sites, which have been implicated in induction of ICAM-1 gene transcription in response to various proinflammatory stimuli (Muller et al. 1995, Ledebur and Parks 1995). It has been identified that the -187/178 on the ICAM-1 promoter is a NF- $\kappa$ B site, which is necessary and sufficient for rhinovirus activating ICAM-1 expression (Papi and Johnston 1999). Thrombin-induced ICAM-1 expression is also mediated by NF- $\kappa$ B activation via protease-activated receptor-1 (PAR-1), which induces binding of both p65/RelA and NFATc1 to the NF- $\kappa$ B binding site of ICAM-1 (Xue et al. 2009); the activation of the JNK pathway likely involves $\mathrm{G} \alpha_{\mathrm{q}}, \mathrm{G} \beta \gamma$, Ras, Rac1 and Src family kinase (Miho et al. 2005). ICAM-1 is a dynamic molecule that is localized in the apical membrane of the endothelium which clusters and aggregates upon binding to leukocyte ligands, such as LFA-1 (Grakoui et al. 1999). A similar process is involved in actin cytoskeleton rearrangement via Rho-like small GTPases family (Burridge and Wennerberg 2004). The cytoplasmic domain of ICAM-1 is composed of 28 amino acids (478-505): RQRKIKKYRLQQAQKGTPMKPNTQATPP (Carpen et al. 1992), this domain does not have intrinsic kinase activity or a Scr homologue domain that can recruit tyrosine-phosphorylated protein, but it does interact with actin-binding proteins, suggesting that ICAM-1 induced signalling may be initiated at the membrane-cytoskeleton interface (Vogetseder and Dierich 1991). ICAM-1 ligation or clustering at the cell surface leads to a range of signalling-mediated activities through cascades involving a number of kinases including p38 MAPK (Mitogen-activated protein kinases)-inducing heatshock protein 27 phosphorylation in pulmonary microvascular ECs, which in turn modulates cytoskeletal rearrangements and neutrophil migration toward EC junctions (Wang et al. 2002). The tyrosine phosphorylation of cytoskeletal proteins, focal adhesion kinase, paxillin, and p130 in cerebral ECs were mediated by Rho activation (Etienne et al. 1998). Experimental cerebral malaria (ECM) infected with $P$. berghei ANKA $(\mathrm{PbA})$ in $\mathrm{C} 57 \mathrm{BL} / 6 \mathrm{~J}$ mice (which has virtually no IE sequestration in the brain but shares features of vessel occlusion and inflammation) has revealed the activation of all key elements in the JNK pathway such as p-MKK4, p-JNK and p-c-Jun in mice brains (Anand and Babu 2011). JNK not only caused c-Jun phosphorylation but also affected the activities of multiple proteins such as ATF2, P53, Elk1 c-Myc and bcl-2 family relating to apoptosis (Liu and Lin 2005), indicating that these pathways and components played critical roles in mediating neuronal cell death during ECM.

The regulation of EC due to $P$. falciparum cytoadherence is seen at the transcriptional level, using microarray analysis of HUVEC transcriptome following in vitro co-culture of IE and HUVEC. This showed significant differential regulation of genes which defined gene ontologies such as cell 
communication, cell adhesion, signal transduction and immune response (Chakravorty et al. 2007). The investigation of global gene responses of human brain microvascular endothelial cells (HBMEC) after the interaction with Pf-IE resulted in the similar results and more specifically, several members of NF- $\kappa B$ signalling cascade was induced with 4 of 5 NF- $\kappa B$ subunits (REL-B, cREL, NF- $\kappa B 1$ and NF- $\mathrm{KB} 2$ ) up-regulated together with significant increase of NF- $\kappa B$ target genes. It was found that one of the NF- $\kappa$ B family members, REL-1A (P65) almost completely translocated into the nuclear compartment within 10 min of IE-EC interaction, suggesting a direct role for parasite factors in NF$\kappa \mathrm{B}$ activation (Tripathi et al. 2009). ICAM-1 was significantly increased upon IE interaction EC and there was a correlation between adherent IEs with this increased level. The interacting IE induced a $730 \%$ increase in ICAM-1 on HBMEC; two NF- $\kappa$ B inhibitors, Bay11-7082 and MG132, were able to reduce IE-induced ICAM-1 up-regulation, Bay117082 completely abolished IE-induced ICAM-1 expression at a concentration of $40 \mathrm{mM}$ (Tripathi et al. 2006). An antioxidant and NF- $\kappa B$ indirect inhibitor, pyrrolidine dithiocarbamate (PDTC), which acts by removing the reactive oxygen species (ROS) intermediates, also had similar functions indicating that ROS may also involved in IE-EC ICAM-1 signalling as IEs can generate a wide variety of ROS (Atamna et al. 1994, Ginsburg and Atamna 1994). How IE are activating NF$\kappa-\mathrm{B}$ in EC is not clear. Possibily, P. falciparumderived glycosylphosphatidylinositol (PfGPI) toxin activates vascular endothelial cells by tyrosine kinase mediated signal transduction, leading to $\mathrm{NF} \kappa \mathrm{B} / \mathrm{c}-\mathrm{rel}$ activation (Schofield et al. 1996). Specific MAPK pathways have been linked to severe malaria through work on the response of macrophages to PfGPI, normally resulting in TNF secretion. A JNK inhibitor alleviated phosphorylation of a number of signalling molecules, and reduced amount of TNF secreted by PfGPI-stimulated macrophages
(Tachado et al. 1996, 1997). More evidence has demonstrated that NF- $\mathrm{KB}$ is essential for ICAM-1 expression induced by inflammatory cytokines (Ledebur and Parks 1995) and neutrophil adhesion (Rahman et al. 1999). The mechanism of NF-kB activation via a variety of extracellular stimuli is unique in that it is induced rapidly and does not require de novo protein synthesis, thereby allowing cells to respond quickly to emergent situations, such as bacterial infection.

\section{CD36 MEDIATED CYTOADESION AND SIGNALLING}

CD36 is expressed on the EC surface and binds to many ligands such as collagen, thrombospondin, oxidized low density lipoprotein, native lipoproteins, oxidized phospholipids and longchain fatty acids (Tandon et al. 1989, Silverstein et al. 1992, Endemann et al. 1993, Nicholson et al. 1995, Calvo et al. 1998, Podrez et al. 2002). CD36 has been shown to be a major sequestration receptor on microvascular endothelial cells. In P. falciparum malaria, CD36 has long been considered a major contributor to pathogenesis by acting as a vascular receptor for the adhesion of IE (Ho and White 1999). It is thought that CD36 is involved in the PfGPI induced MAPK activation and proinflammatory cytokine secretion, and has been shown to have a role in the innate immune response to malaria in mouse models. Protein kinase C (PKC)-dependent sequence RGPYTYRVRFLA is a target of $\mathrm{Thr}^{92}$ phosphorylated CD36 in endothelium (Daviet and Mcgregor 1997), and there is minimal binding domain with 179-amino-acid peptide located in exon 1 of PfEMP-1 that anchors CD36 and induces an intracellular signal (Yipp et al. 2003b). In an immunohistochemistry study examining the distribution of sequestration receptors in different organs from fatal cases of P. falciparum malaria and non-infected controls, fatal malaria was associated with significantly higher levels of ICAM-1 and E-selectin expression on vessels in the brain, as 
well as CD36, but CD36 and thrombospondin staining were thinly scattered in this tissue (Turner et al. 1994). Adhesion receptors have co-operative functions that contribute to cytoadherence. As shown by single-molecule force spectroscopy technique, both CD36 and TSP are involved in specific ligandreceptor interactions, but CD36-mediated signal molecule interactions were more stable than TSP, although the TSP-IE interaction was stronger than the CD36-IE interaction in the high pulling rate regime, indicating that TSP mediated interactions may initiate cytoadhesion whereas CD36 might function to stabilise binding (Li et al. 2011). ICAM-1 and CD36 have been shown in ex vivo binding assays to synergize to mediate adherence of Pf-IE to cultured human microvascular EC (Mccormick et al. 1997). It has also been reported that cytoadhesion of CSA-binding IEs on EC can inhibit the cytoadhesion of CD36-binding IEs, which is mediated by a CD44-transduced signal on SBEC-1D (Saimiri sciureus brain EC) cells. Two elements from signal transduction pathways Srckinase and MAP-kinase were identified downstream of CD44 receptor (Jurzynski et al. 2007).

The mechanisms of intracellular signalling events have been studied extensively using parallel plate flow chamber in vitro assays or in intact human microvessels in a human/severe combined immunodeficient (SCID) mouse model in vivo. These have demonstrated major roles for CD36 in IE cytoadherence on microvascular endothelial cells. A recombinant peptide corresponding to the minimal CD36-binding domain in PfEMP1 can inhibit and even reverse the IE adhesion of clinical isolates, and an anti-CD36 monoclonal antibody can inhibit IE binding both in vitro and in vivo (Yipp et al. 2003a). ICAM-1 appears to stabilize the IE-CD36 interaction without an increase in the number of IE recruited to the endothelium, while the induction of P-selectin can increase the number of rolling IEs which subsequently adhere to CD36 (Ho et al. 2000). Treatment of HDMECs with a
Src-family kinase-selective inhibitor (PP1) resulted in a significant reduction of IE adhesion by $72 \%$ in a flow-chamber assay. The effect of PP1 could be mimicked by a specific alkaline-phosphatase inhibitor levamisole. These results pointed to the use of inhibitors for Src-family kinases and ectoalkaline phosphatase therapeutically (see below) (Yipp et al. 2003a). Binding of IE to HDMEC also resulted in the downstream activation of the MAPK pathway, but inhibition of the extracellular signalregulated kinase $1 / 2($ ERK $1 / 2)$ and p38 MAP kinase pathways had no immediate effect on IE adhesion, although the mitogen-activated protein (MAP) kinase pathway activation was Src-family kinase dependent. NIH 3 T3 cells transfected with wild-type CD36 or a mutant protein in which $\mathrm{Thr}^{92}$ was substituted by Ala were used as a model to support the rolling and adhesion of IEs under flow conditions. It was also shown that the target of the alkaline phosphatase is the ectodomain of CD36 at threonine-92 $\left(\mathrm{Thr}^{92}\right)$, and this regulated IE adhesion to $\mathrm{CD} 36$ under flow conditions in a Src family kinase and alkaline phosphatase dependent manner. A molecular mechanism underlying IE-CD36 binding has been proposed: CD36 is constitutively phosphorylated; upon initial IE adhesion and subsequent Src family kinase activation, CD36 becomes dephosphorylated through the activation of an ecto-alkaline phosphatase, which is expressed on the surface of endothelial cells. Dephosphorylated CD36 binds to IE with higher affinity than to phosphorylated CD36 (Ho et al. 2005).

\section{SIGNALLING INSIDE IEs}

Sicard et al have shown that P. falciparum infection induced modulation of the host PAK $1 \rightarrow$ MEK1 pathway and the pharmacological interference with this pathway using highly specific allosteric inhibitors of human PAK and MEK enzymes caused a block of parasite proliferation in both liver 
and blood stages of parasites (Sicard et al. 2011). The role of signalling in Pf-IE has not been studied extensively in relation to cytoadherence except for one study on casein kinase inhibition and its effect on adhesion (Hora et al. 2009).

Extracellular domains of PfEMP1 are variable and bind various host endothelial receptors, whereas their cytoplasmic domains (VARCs) are relatively conserved with binding affinity to $P$. falciparum knob-associated histidine-rich protein (KAHRP). The interaction of VARC and KAHRP was affected by PfEMP1 phosphorylation on VARC and was considered as an important parameter in cytoadherence. By using specific inhibitors and enhancers, an enzyme responsible for VARC phosphorylation has been identified as erythrocytic casein kinase II (CKII) and a set of cell-permeable CKII inhibitors have been tested on cytoadhesion of IEs to soluble EC receptors. These inhibitors possibly block or reverse the interaction between VARC and its binding partners, and so have the ability to reduce cytoadherence and could be considered in the development of therapies against severe malaria.

\section{CytoAdHerence of P. FALCIPARUM Mediated By Platelets}

Increasing evidence shows that platelets may be involved in CM pathogenesis. Platelets have recently been shown to accumulate in brain microvessels of patients with $\mathrm{CM}$ and to modulate the binding of $P$. falciparum-infected red cells to human brain endothelium in vitro (Wassmer et al. 2006a). Several groups have suggested that platelet-mediated clumping of IEs to form apparent auto-agglutinates is a common adhesive phenotype in severe malaria (Wassmer et al. 2008, Mayor et al. 2011) although others have questioned this (Arman etal. 2007). Using a platelet-endothelial cell co-culture model, Wassmer et al. 2006b have investigated the mechanisms by which platelets modify the function of HBMEC, and have found that platelets have a pro-apoptotic effect on TNF-activated HBMEC in a contact-dependent manner and the supernatants of thrombin-activated platelets killed TNF-stimulated HBMEC. TGF-1 was found as a major molecule involved in endothelial cell death (Wassmer et al. 2006b), which could be a mechanism of microvascular damage during human CM. The interaction of $P$. falciparum with platelets might also lead to platelet activation and release of inflammatory mediators such as platelet factor 4 (PF4)/CXCL4 by moderating the effects of heparinlike molecules on ECs (Srivastava et al. 2008). However, purified human platelets killed cultured P. falciparum IE and platelet-deficient or aspirintreated mice were more susceptible to death during P. chabaudi infection, indicated the protective aspect of platelets in early stage of erythrocytic infection (Mcmorran et al. 2009). Several EC receptors are likely responsible for platelet-mediated IE cytoadhesion including P-selectin (CD62P) (Udomsangpetch et al. 1997); Thrombospondin (TSP) (Roberts et al. 1985); Platelet endothelial cell adhesion molecule 1 (PECAM1 or CD31) (Treutiger et al. 1997, Heddini et al. 2001), globular $\mathrm{C} 1 \mathrm{q}$ receptor $(\mathrm{gC} 1 \mathrm{qR} / \mathrm{HABP} 1 / \mathrm{p} 32)$ (Biswas et al. 2007) and CD36 (Pain et al. 2001). It has also been shown that platelets expressing CD36 serve as a bridge to bind IEs via PfEMP1 to the endothelial cell membrane either directly (Wassmer et al. 2004) or through ultra-large von Willebrand factor strings (Bridges et al. 2010).

The transcriptional changes of HBMEC in response to platelets in the presence or the absence of TNF and IEs have been analyzed by Barbier et al. 2011. The platelets induced the expression of genes involved in inflammation and apoptosis and altered canonical pathways such as chemokines, TGF $\beta$, death-receptors, erythropoietin and TREM1-signalling (Barbier et al. 2011), supporting the hypothesis that platelets play a pathogenic role in CM. The platelet mediated cytoadhesion also involved the activation of Weibel-Palade (WP) bodies and release of von Willebrand factor 
(VWF) (Hollestelle et al. 2006). Released VWF is in an activated conformation that could interact with platelet receptor gpIa/V/IV and trigger intravascular platelet aggregation (Groot et al. 2007). Ultra-large VWF multimers are 'unfurled' under flow, presenting a highly adherent platform for platelet recruitment and subsequent IE adhesion via platelet-expressed CD36. Induction of this pathway in vitro is very rapid with significant levels of VWF available for platelet adhesion within minutes of WP body activation, making this an attractive mechanism for efficient cytoadherence early in infection. Interestingly, such an IE proadhesive state can be removed through the action of the VWF protease ADAMTS-13 (a disintegrin and metalloproteinase with a thrombospondin type 1 motif, member 13) that rapidly clears ultra-large VWF on ECs (Dong et al. 2002), but activity of this enzyme is reduced in severe malaria (De Mast et al. 2009, Larkin et al. 2009, Lowenberg et al. 2010).

\section{CYTOADHERENCE INHIBITION VIA SIGNAL}

TRANSDUCTION PATHWAYS

The importance of signal transduction in Plasmodium infection has been also obtained using known inhibitors of the signalling system. Many of these inhibitors are drugs already in clinical use, which makes them more feasible as therapeutic agents in anti-malaria regimes. For example, the in vitro anti-plasmodial activity of antioxidant compounds, Flavonoids, from Artemisia annua $L$ has recently been reported as protein kinases inhibitor that able to several kinases including Akt/protein kinase B (Akt/ PKB), Fyn, Janus kinase 1 (JAK1), mitogen-activated protein kinase kinase 1 (MEK1), phosphoinositide 3-kinase (PI3K), mitogen-activated protein (MAP) kinase, kinase 4 (MKK4), Raf1, and zeta chainassociated $70-\mathrm{kDa}$ protein (ZAP-70) kinase (Hou and Kumamoto 2010). Artemisinin has also been shown to inhibit nuclear translocation of NF-KB complex (Aldieri et al. 2003).
Levamisole is a specific alkaline-phosphatase inhibitor, has been shown in vitro to inhibit of sequestration of Pf-IE to endothelium. It has been used in a pilot clinical study for uncomplicated malaria, which resulted in increased peripheral blood parasitaemia of mature $P$. falciparum IE 24 hours after Levamisole administration. The sequestration ratio (between observed and expected peripheral blood parasitaemia) of early trophozoite and midtrophozoite parasites increased after Levamisole treatment, with near complete prevention of early trophozoites sequestration and $>65 \%$ prevention of mid-trophozoite sequestration. These findings strongly suggest that levamisole decreases iRBC sequestration in $P$. falciparum malaria in vivo (Dondorp et al. 2007). Such an inhibitor for ecto-alkaline phosphatase could be exploited therapeutically although it may work through other mechanisms such inhibition of ion channel blockade and platelet aggregation (Mun et al. 1998). Levamisole could enhance immune response towards Thelper 1 development through the activation of dendritic cells or $\mathrm{T}$ cell aspects (Chen et al. 2008). It has been reported that Levamisole inhibited rat platelet aggregation by releasing of a prostacyclin-like factor in vivo (Pinto et al. 1990).

Recently a rho-kinase inhibitor Fasudil, a drug already in clinical use for cardio- and neurovascular diseases, was successfully tested on laboratory strains of $P$. falciparum using an in vitro co-culture model. It was shown that adhesion of IE to primary human lung endothelial cells (HLECs) activated the Rho kinase signalling pathway, which led to endothelial barrier permeabilization. When Fasudil was added concomitantly with IE, this decreased both NF- $\mathrm{KB}$ activation and endothelial cell apoptosis. Fasudil also helped to restore endothelial barrier integrity after IE adhesion. Rho kinase inhibition thus appears to be a promising adjunctive therapeutic agent for severe malaria (Taoufiq et al. 2008). Fasudil was also tested in patient isolates at schizont stage in contact and non- 
contact experiments with HLEC. In both conditions, $30 \mu \mathrm{M}$ Fasudil significantly reduced $P$. falciparummediated HLEC apoptosis after 24 hours, but it did not decrease significantly $P$. falciparum cytoadherence (Zang-Edou et al. 2010, WaknineGrinberg et al. 2010). It has been reported that the anti-inflammatory effect of the Rho kinase inhibitor fasudil was via inhibition of NF- $\mathrm{KB}$ activation in rheumatoid arthritis (Okamoto et al. 2010).
Atorvastatin is a cholesterol-lowering medication and is widely used in patients with cardiovascular disorders. It has been shown that atorvastatin protected EC from senescence and apoptosis. The molecular mechanism of this protection is correlated with the activation of the anti-apoptotic inositol triphosphate (PI3)-Akt kinase pathway, resulting in the phosphorylation of endothelial nitric oxide synthase (Kureishi et

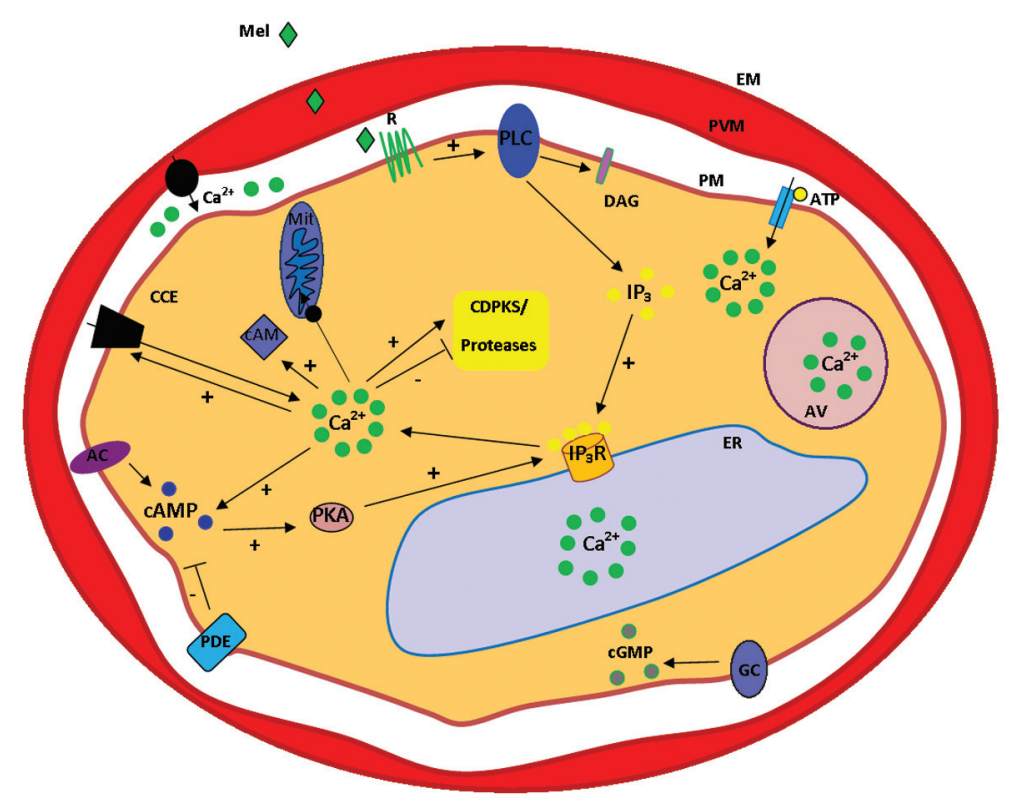

Figure 1. Schematic model for calcium signalling in intraerythrocitic stages of Plasmodium. Calcium signalling in intraerythrocitic stages of Plasmodium. Melatonin (Mel) binds a putative receptor (R) at the parasite membrane (PM), leading to the activation of a phospholipase C (PLC), which generates the second messengers diacylglycerol (DAG) and inositol 1,4,5 triphosphate $\left(\mathrm{IP}_{3}\right) . \mathrm{IP}_{3}$ binds to putative $\mathrm{IP}_{3}$ receptors $\left(\mathrm{IP}_{3} \mathrm{R}\right)$ located at the membrane of the endoplasmic reticulum (ER), leading to the release of calcium $\left(\mathrm{Ca}^{2+}\right) . \mathrm{Ca}^{2+}$ rise in the parasite cytosol is responsible for the activation of numerous downstream effectors, as calmodulin (cAM), calcium-dependent protein kinases (CDPKs) and proteases, as well as generating further $\mathrm{Ca}^{2+}$ increase in the cytosol via influx from the plasma membrane, a process known as capacitative calcium entry $(\mathrm{CCE}) . \mathrm{Ca}^{2+}$ may also enter the mitochondria (Mit), activating its metabolism. $\mathrm{Ca}^{2+}$ is also able to induce an increase in cyclic adenosine monophosphate (cAMP) in the cytosol, whose production is regulated by adenylyl cyclase (AC) and phosphodiesterase (PDE). cAMP is able to promote further calcium increase from the ER. Besides the ER, calcium is also stocked in intracellular acidic pools (AC). The parasitophorous vacuole is a milieu rich in $\mathrm{Ca}^{2+}$. Adenosine triphosphate (ATP) is able to induce calcium influx from the external milieu via putative purinergic-like receptors. Guanylate cyclase (GC) activity, which leads to the production of cyclic guanosine monophosphate (cGMP) is also implicated in cell cycle signalling to initiate gametogenesis and progression of schizogony. EM: erythrocyte membrane, PVM: parasitophorous vacuole membrane. 


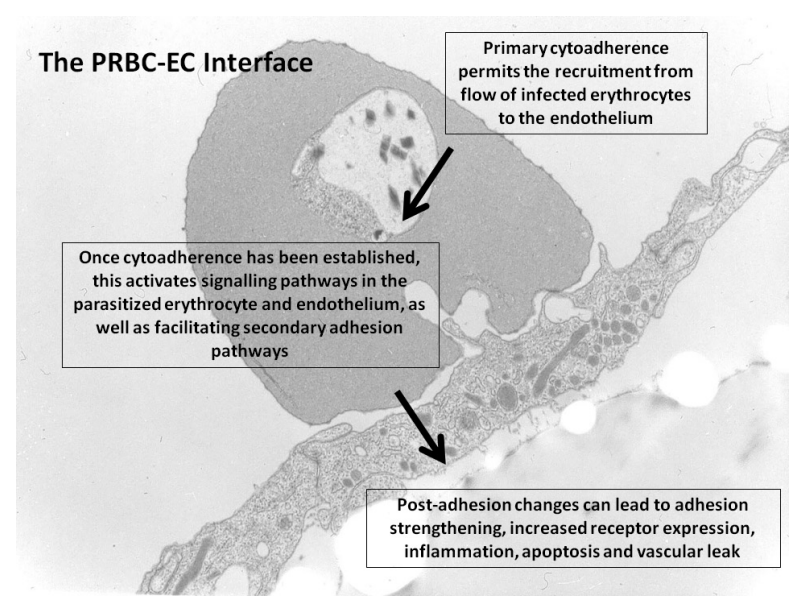

Figure 2. Summary figure for cytoadherence linked signalling showing interface of Plasmodium falciparum infected erythrocyte (PRBC) and endothelial cell (EC).

al. 2000). Atorvastatin decreases ICAM-1 expression in stimulated EC and monocytes (Romano et al. 2000). The roles of atorvastatin in the activation of cell survival protein kinase B or Akt signalling pathway is well established (Mason 2003, Wolfrum et al. 2003). The rho-kinase pathway in many aspects is antagonistic to PI3K/ Akt/eNOS endothelial cell survival pathway (Zhou and Liao 2009). Recently, co-culture using mature P. falciparum 3D7 and primary HLEC IEinduced increased levels of endothelial adhesion molecules, ICAM-1 and P-selectin. Pre-treatment of EC with atorvastatin significantly prevented this up-regulation, protected endothelial cells from IE-induced apoptosis and protected endothelial barrier integrity from IE-induced impairment. The increased Akt expression in HLEC exposed to IE was observed by both Western blot and confocal microscopy techniques (Taoufiq et al. 2011).

\section{CONCLUSIONS}

Taken together $\mathrm{Ca}^{2+}$ mediated signalling offers potentials new molecular targets for the development of novel antimalarial. Several studies have explored the possibilities of using existing medications as therapeutic modalities to reduce IE sequestration e.g. Src-family kinases, ecto-alkaline phosphatase, rho-kinase and AKT activator. However, the regulation of signalling pathways is complicated and results are difficult to interpret due to the interconnection of different signalling pathways via protein networks which are controlled by multiple positive and negative feedback mechanisms. Some pathways in certain situation may be redundant, some activation may only be transient and some key components of pathways could often be shared by multiple signalling cascades. More elegant methods and techniques are needed to elucidate the molecular mechanism mediating cytoadhesion and thereby find the key issues in these for the design of new therapies to control disease.

\section{ACKNOWLEDGMENTS}

C.R.S. Garcia is a Conselho Nacional de Desenvolvimento Científico e Tecnológico (CNPq) fellow and the work is supported by Fundação de Amparo à Pesquisa do Estado de São Paulo(FAPESP) (07/52924-0), by Malaria Programa de Apoio a Núcleos de Excelência (Pronex), and by an INCTINBqMed. LNC received FAPESP Fellowship.

\section{RESUMO}

A Malária é responsavel por mais de 1.5 milhões de mortes anualmente, especialmente entre crianças (Snow et al. 2005). Apesar da gravidade da situação e grande esforço para o desenvolvimento de novas drogas (Yuan et al. 2011), os investimentos em drogas antimaláricas ainda é relativamente baixo. Brevemente, os alvos antimaláricos atualmente testados incluem: quinases, proteases, canais iônicos para GPCR, receptores nucleares entre outros (Gamo et al. 2010). No presente trabalho nós revisamos as vias de transdução de sinal em eritrócitos assim como eritrócitos infectados e interações com células endoteliais, denominada citoaderência. Este processo é conhecido por sua importante função na patogenicidade da malária severa. As moléculas expressas na superfície dos 
eritrócitos infectados (IE) e células endoteliais vasculares (EC) são importantes mediadores da citoaderência, não apenas induzindo mudanças estruturais e metabólicas nos dois lados, mas também desencadeiam diversos sinais do processo transducional, levando a alteração da expressão gênica, com o balanço entre a regulação positiva e negativa determinando a patologia endotelial durante a infecção malárica.

Palavras-chave: citoaderência, eritrócito, malária, Plasmodium, transdução de sinal.

\section{REFERENCES}

AKKaYA C, ShUmilina E, BobBalla D, BRAND VB, Mahmud H, LANG F AND HuBER SM. 2009. The Plasmodium falciparum-induced anion channel of human erythrocytes is an ATP-release pathway. Pflugers Arch 457: 1035-1047.

ALdiERIE, ATRAGENED, BERgandi L, Riganti C, COSTAMAGNA C, Bosia A AND GHIGO D. 2003. Artemisinin inhibits inducible nitric oxide synthase and nuclear factor NF-kB activation. FEBS Lett 552: 141-144.

Alessi DR, ANDJELKovic M, CAudwell B, CRON P, Morrice N, CoHen P AND Hemmings BA. 1996. Mechanism of activation of protein kinase B by insulin and IGF-1. EMBO J 15: 6541-6551.

Alves E, Bartlett PJ, Garcia CR And Thomas AP. 2010. Melatonin and IP3-induced $\mathrm{Ca} 2+$ release from intracellular stores in the malaria parasite Plasmodium falciparum within infected red blood cells. J Biol Chem 286: 5905-5912.

ANAND SS AND BABU PP. 2011. c-Jun N terminal kinases (JNK) are activated in the brain during the pathology of experimental cerebral malaria. Neurosci Lett 488: 118-122.

ANDJELKOVIC M, ALESSI DR, MEIER R, FERNANDEZ A, LAMB NJ, FreCh M, CRON P, COHEN P, LUCOCQ JM AND HeMmINGS BA. 1997. Role of translocation in the activation and function of protein kinase B. J Biol Chem 272: 31515-31524.

ARASTU-KAPUR S, PONDER EL, FONOVIC UP, YeOH S, YUAN F, FonOVIC M, GRAINGER M, PHILLIPS CI, POWERS JC AND BogYo M. 2008. Identification of proteases that regulate erythrocyte rupture by the malaria parasite Plasmodium falciparum. Nat Chem Biol 4: 203-213.

Arman M, RaZA A, Tempest LJ, LyKe KE, Thera MA, Kone A, Plowe CV, Doumbo OK AND Rowe JA. 2007. Plateletmediated clumping of Plasmodium falciparum infected erythrocytes is associated with high parasitemia but not severe clinical manifestations of malaria in African children. Am J Trop Med Hyg 77: 943-946.

Atamna H, Pascarmona G And Ginsburg H. 1994. Hexosemonophosphate shunt activity in intact Plasmodium falciparum-infected erythrocytes and in free parasites. Mol Biochem Parasitol 67: 79-89.
BAgNARESI P, Alves E, DA SILVA HB, EPIPHANIO S, MOTA MM AND GARCIA CR. 2009. Unlike the synchronous Plasmodium falciparum and P. chabaudi infection, the P. berghei and P. yoelii asynchronous infections are not affected by melatonin. Int J Gen Med 2: 47-55.

BARBIER M ET AL. 2011. Platelets alter gene expression profile in human brain endothelial cells in an in vitro model of cerebral malaria. PLoS One 6: e19651.

BARNWELL JW, ASCH AS, NACHMAN RL, YAMAYA M, AIKAWA M AND INGRAVALLO P. 1989. A human 88-kD membrane glycoprotein (CD36) functions in vitro as a receptor for a cytoadherence ligand on Plasmodium falciparum-infected erythrocytes. J Clin Invest 84: 765-772.

BERALDO FH, ALMEIDA FM, DA SILVA AM AND GARCIA CR. 2005. Cyclic AMP and calcium interplay as second messengers in melatonin-dependent regulation of Plasmodium falciparum cell cycle. J Cell Biol 170: 551-557.

Beraldo FH, Mikoshiba K And Garcia CR. 2007. Human malarial parasite, Plasmodium falciparum, displays capacitative calcium entry: 2-aminoethyl diphenylborinate blocks the signal transduction pathway of melatonin action on the P. falciparum cell cycle. J Pineal Res 43: 360-364.

BerendT AR, Simmons DL, TANSEy J, NewBold CI AND MARSH K. 1989. Intercellular adhesion molecule-1 is an endothelial cell adhesion receptor for Plasmodium falciparum. Nature 341: 57-59.

BILlKER O, DECHAMPS S, TEWARI R, WENIG G, FranKE-FAYARD B AND BRINKMANN V. 2004. Calcium and a calciumdependent protein kinase regulate gamete formation and mosquito transmission in a malaria parasite. Cell 117: 503-514.

Biswas AK, Hafiz A, BANERJEE B, Kim KS, DATta K AND CHITNIS CE. 2007. Plasmodium falciparum uses $\mathrm{gClqR} /$ $\mathrm{HABP} 1 / \mathrm{p} 32$ as a receptor to bind to vascular endothelium and for platelet-mediated clumping. PLoS Pathog 3: 1271-1280.

BLACKMAN MJ. 2008. Malarial proteases and host cell egress: an 'emerging' cascade. Cell Microbiol 10: 1925-1934.

BODDEY JA ET AL. 2010. An aspartyl protease directs malaria effector proteins to the host cell. Nature 463: 627-631.

Bridges DJ, BunN J, VAN MouriK JA, Grau G, Preston RJ, MolyneuX M, COMBES V, O'DONNELl JS, DE LAAT B AND CRAIG A. 2010. Rapid activation of endothelial cells enables Plasmodium falciparum adhesion to platelet-decorated von Willebrand factor strings. Blood 115: 1472-1474.

Budu A, Peres R, Bueno VB, Catalani LH ANd Garcia CR. 2007. N1-acetyl-N2-formyl-5-methoxykynuramine modu-lates the cell cycle of malaria parasites. J Pineal Res 42: $261-266$

Burridge K AND Wennerberg K. 2004. Rho and Rac take center stage. Cell 116: 167-179.

CALVo D, Gomez-Coronado D, SUAREZ Y, LASUnCION MA AND VEGA MA. 1998. Human CD36 is a high affinity receptor for the native lipoproteins HDL, LDL, and VLDL. J Lipid Res 39: 777-788.

CARLton JM ET AL. 2008. Comparative genomics of the neglected human malaria parasite Plasmodium vivax. Nature 455: 757-763. 
Carpen O, Pallai P, Staunton DE And SPringer TA. 1992. Association of intercellular adhesion molecule-1 (ICAM-1) with actin-containing cytoskeleton and alpha-actinin. J Cell Biol 118: 1223-1234.

Chakravorty SJ, Carret C, Nash GB, IVEns A, Szestak T AND CRAIG AG. 2007. Altered phenotype and gene transcription in endothelial cells, induced by Plasmodium falciparum-infected red blood cells: pathogenic or protective? Int J Parasitol 37: 975-987.

Chakravorty SJ, Hughes KR and Craig AG. 2008. Host response to cytoadherence in Plasmodium falciparum. Biochem Soc Trans 36: 221-228.

Chandramohanadas R, Davis PH, Beiting DP, Harbut MB, Darling C, Velmourougane G, Lee MY, Greer PA, Roos DS AND GREENBAUM DC. 2009. Apicomplexan parasites co-opt host calpains to facilitate their escape from infected cells. Science 324: 794-797.

CHEN LY, LIN YL AND CHIANG BL. 2008. Levamisole enhances immune response by affecting the activation and maturation of human monocyte-derived dendritic cells. Clin Exp Immunol 151: 174-181.

Chen S, Dell EJ, Lin F, SAi J And Hamm HE. 2004. RACK1 regulates specific functions of Gbetagamma. J Biol Chem 279: 17861-17868.

Clark IA, Budd AC, Alleva LM AND Cowden WB. 2006. Human malarial disease: a consequence of inflammatory cytokine release. Malar J 5: 85 .

Coppi A, TEWARI R, BISHOP JR, BENNETt BL, LAWRENCE R, ESKO JD, BILLKER O AND SINNIS P. 2007. Heparan sulfate proteoglycans provide a signal to Plasmodium sporozoites to stop migrating and productively invade host cells. Cell Host Microbe 2: 316-327.

Cruz LN, Alves E, LEAL MT, Juliano MA, Rosenthal PJ, JULIANO L AND GARCIA CR. 2011. FRET peptides reveal differential proteolytic activation in intraerythrocytic stages of the malaria parasites Plasmodium berghei and Plasmodium yoelii. Int J Parasitol 41: 363-372.

Cruz LN, Juliano MA, Budu A, Juliano L, Holder AA, BLACKMAN MJ AND GARCIACR. In press. ExtracellularATP triggers proteolysis and cytosolic $\mathrm{Ca} 2+$ rise in Plasmodium berghei and Plasmodium yoelii malaria parasites. Malar J.

DAVIET L AND MCGREGOR JL. 1997. Vascular biology of CD36: roles of this new adhesion molecule family in different disease states. Thromb Haemost 78: 65-69.

De MASt Q ET AL. 2009. ADAMTS13 deficiency with elevated levels of ultra-large and active von Willebrand factor in P. falciparum and P. vivax malaria. Am J Trop Med Hyg 80: 492-498.

De Rasmo D, PANelli D, SARDANELli AM AND PAPA S. 2008. cAMP-dependent protein kinase regulates the mitochondrial import of the nuclear encoded NDUFS4 subunit of complex I. Cell Signal 20: 989-997.

DOERIG C ET AL. 2010. Malaria: targeting parasite and host cell kinomes. Biochim Biophys Acta 1804: 604-612.
DONDORP AM, SILAMUT K, CHARUNWATTHANA P, CHUASUWANChai S, RuANGVEERAYUT R, KRINTRATUN S, WHITE NJ, HO M AND DAY NP. 2007. Levamisole inhibits sequestration of infected red blood cells in patients with falciparum malaria. J Infect Dis 196: 460-466.

Dong JF, Moake JL, Nolasco L, Bernardo A, Arceneaux W, SHRIMPTON CN, SCHAdE AJ, MCINTIRE LV, FuJIKAWA K AND LOPEZ JA. 2002. ADAMTS-13 rapidly cleaves newly secreted ultralarge von Willebrand factor multimers on the endothelial surface under flowing conditions. Blood 100: 4033-4039.

ENDEMANn G, StANTON LW, MADDEN KS, BRyANT CM, White RT AND PROTTER A A. 1993. CD36 is a receptor for oxidized low density lipoprotein. J Biol Chem 268: 11811-11816.

ESSLINGER CW, PICOT S AND AMBroISE-ThOMAS P. 1994. Intraerythrocytic Plasmodium falciparum induces upregulation of inter-cellular adhesion molecule-1 on human endothelial cells in vitro. Scand J Immunol 39: 229-232.

Etienne S, Adamson P, Greenwood J, Strosberg AD, CAZAUBON S AND COURAUd PO. 1998. ICAM-1 signaling pathways associated with Rho activation in microvascular brain endothelial cells. J Immunol 161: 5755-5761.

FARIAS SL, GAZARINI ML, MELO RL, HiRATA IY, JULIANO MA, JULIANO L AND GARCIA CR. 2005. Cysteine-protease activity elicited by $\mathrm{Ca} 2+$ stimulus in Plasmodium. Mol Biochem Parasitol 141: 71-79.

FLECK SL ET AL. 2003. Suramin and suramin analogues inhibit merozoite surface protein-1 secondary processing and erythrocyte invasion by the malaria parasite Plasmodium falciparum. J Biol Chem 278: 47670-47677.

GAMO FJ ET AL. 2010. Thousands of chemical starting points for antimalarial lead identification. Nature 465: 305-310.

Garcia CR, De Azevedo MF, Wunderlich G, Budu A, Young JA AND BANNISTER L. 2008. Plasmodium in the postgenomic era: new insights into the molecular cell biology of malaria parasites. Int Rev Cell Mol Biol 266: 85-156.

GAZARINI ML, BERALDO FH, ALMEIDA FM, BOOTMAN M, DA SILVA AM AND GARCIA CR. 2011. Melatonin triggers PKA activation in the rodent malaria parasite Plasmodium chabaudi. J Pineal Res 50: 64-70.

GAZARINI ML AND GARCIA CR. 2004. The malaria parasite mitochondrion senses cytosolic $\mathrm{Ca} 2+$ fluctuations. Biochem Biophys Res Commun 321: 138-144.

GINSBURG HAND ATAMNA H. 1994. The redox status of malariainfected erythrocytes: an overview with an emphasis on unresolved problems. Parasite 1: 5-13.

Goll DE, Thompson VF, Li H, WeI W AND Cong J. 2003. The calpain system. Physiol Rev 83: 731-801.

GraKoui A, Bromley SK, SUMEN C, DAVIS MM, SHAW AS, ALLEN PM AND DUSTIN ML. 1999. The immunological synapse:a molecular machine controlling $\mathrm{T}$ cell activation. Science 285: 221-227.

Gray C, MCCORMICK C, TURNER GAND CRAIG A. 2003. ICAM-1 can play a major role in mediating $\mathrm{P}$. falciparum adhesion to endothelium under flow. Mol Biochem Parasitol 128: 187-193. 
Groot E, De Groot PG, Fijnheer R And Lenting PJ. 2007. The presence of active von Willebrand factor under various pathological conditions. Curr Opin Hematol 14: 284-289.

HALL NET AL. 2005. A comprehensive survey of the Plasmodium life cycle by genomic, transcriptomic, and proteomic analyses. Science 307: 82-86.

HARPER JF AND HARMON A. 2005. Plants, symbiosis and parasites: a calcium signaling connection. Nat Rev Mol Cell Biol 6: 555-566.

Heddini A, Chen Q, Obiero J, Kai O, Fernandez V, Marsh K, Muller WA and WaHLgren M. 2001. Binding of Plasmodium falciparum-infected erythrocytes to soluble platelet endothelial cell adhesion molecule-1 (PECAM-1/ CD31): frequent recognition by clinical isolates. Am J Trop Med Hyg 65: 47-51.

Ho M, Hickey MJ, MurRay AG, ANDONEGUi G AND Kubes P. 2000. Visualization of Plasmodium falciparum-endothelium interactions in human microvasculature: mimicry of leukocyte recruitment. J Exp Med 192: 1205-1211.

Ho M, HoAng HL, LeE KM, Liu N, Macrae T, Montes L, Flatt CL, Yipp BG, Berger BJ, LOOAREESUWAN S AND RoBBINS SM. 2005. Ectophosphorylation of CD36 regulates cytoadherence of Plasmodium falciparum to microvascular endothelium under flow conditions. Infect Immun 73: 8179-8187.

Ho M, Schollaardt T, NiU X, Looareesuwan S, Patel KD AND KUBES P. 1998. Characterization of Plasmodium falciparum-infected erythrocyte and P-selectin interaction under flow conditions. Blood 91: 4803-4809.

Ho M AND WHite NJ. 1999. Molecular mechanisms of cytoadherence in malaria. Am J Physiol 276: C1231-1242.

Hollestelle MJ, Donkor C, Mantey EA, Chakravorty SJ, Craig A, AKoto AO, O'Donnell J, VAN MOURIK JA AND BUNN J. 2006. Von Willebrand factor propeptide in malaria: evidence of acute endothelial cell activation. Br J Haematol 133: 562-569.

Hora R, Bridges DJ, Craig A AND Sharma A. 2009. Erythrocytic casein kinase II regulates cytoadherence of Plasmodium falciparum-infected red blood cells. J Biol Chem 284: 6260-6269.

HotTA CT, GAZARINI ML, BERALDO FH, VAROTTI FP, LOPES C, MARKUS RP, POZZAN T AND GARCIA CR. 2000. Calciumdependent modulation by melatonin of the circadian rhythm in malarial parasites. Nat Cell Biol 2: 466-468.

Hou DX AND KuMAMOTO T. 2010. Flavonoids as protein kinase inhibitors for cancer chemoprevention: direct binding and molecular modeling. Antioxid Redox Signal 13: 691-719.

ISHINO T, ORITO Y, CHINZEI Y AND YUDA M. 2006. A calciumdependent protein kinase regulates Plasmodium ookinete access to the midgut epithelial cell. Mol Microbiol 59: $1175-1184$.

JURZYNSKI C, GYSIN J AND POUVELLE B. 2007. CD44, a signal receptor for the inhibition of the cytoadhesion of CD36binding Plasmodium falciparum-infected erythrocytes by CSA- binding infected erythrocytes. Microbes Infect 9: 1463-1470.
KATO N ET AL. 2008. Gene expression signatures and smallmolecule compounds link a protein kinase to Plasmodium falciparum motility. Nat Chem Biol 4: 347-356.

KEBAIER CAND VANDERBERG JP. 2010. Initiation of Plasmodium sporozoite motility by albumin is associated with induction of intracellular signaling. Int J Parasitol 40: 25-33.

KoYAMAFC, CHAKRABARTI DAND GARCIACR. 2009. Molecular machinery of signal transduction and cell cycle regulation in Plasmodium. Mol Biochem Parasitol 165: 1-7.

Kumar A, VAid A, Syin C AND Sharma P. 2004. PfPKB, a novel protein kinase B-like enzyme from Plasmodium falciparum: I. Identification, characterization, and possible role in parasite development. J Biol Chem 279: 24255-24264.

Kureishi Y, Luo Z, SHiojima I, BiALIK A, Fulton D, LeFER D J, Sessa WC AND Walsh K. 2000. The HMG-CoA reductase inhibitor simvastatin activates the protein kinase Akt and promotes angiogenesis in normocholesterolemic animals. Nat Med 6: 1004-1010.

LANGHorne J, Ndungu FM, SponaAs AM AND Marsh K. 2008. Immunity to malaria: more question than answers. Nature Immunol 9: 725-732.

LANZER M, WiCKERT H, KROHNE G, VINCENSINI LAND BRAUN BRETON C. 2006. Maurer's clefts: a novel multi-functional organelle in the cytoplasm of Plasmodium falciparuminfected erythrocytes. Int J Parasitol 36: 23-36.

LARKIN D ET AL. 2009. Severe Plasmodium falciparum malaria is associated with circulating ultra-large von Willebrand multimers and ADAMTS13 inhibition. PLoS Pathog 5: e1000349.

LEDEBUR HC AND PARKS TP. 1995. Transcriptional regulation of the intercellular adhesion molecule-1 gene by inflammatory cytokines in human endothelial cells. Essential roles of a variant NF-kappa B site and p65 homodimers. J Biol Chem 270: 933-943.

LEECH JH, BARNWELL JW, MILLER LH AND HOWARD RJ. 1984. Identification of a strain-specific malarial antigen exposed on the surface of Plasmodium falciparum-infected erythrocytes. J Exp Med 159: 1567-1575.

LEVANO-GARCIA JARD, DLUZEWSKI A, MARKus RP AND GARCIA CRS. 2011. Purinergic signaling is involved in the malaria parasite Plasmodium falciparum invasion to red blood cells. Purinergic Signaling 6: 365-372.

Li A, LIM TS, SHI H, YIN J, TAN SJ, Li Z, LOW BC, TAN KS AND LIM CT. 2011. Molecular mechanistic insights into the endothelial receptor mediated cytoadherence of Plasmodium falciparum-infected erythrocytes. PLoS One 6: e16929.

LIU J AND LIN A. 2005. Role of JNK activation in apoptosis: a Double-edged sword. Cell Res 15: 36-42.

LOVETT JL AND SIBLEY LD. 2003. Intracellular calcium stores in Toxoplasma gondii govern invasion of host cells. J Cell Sci 116: 3009-3016.

LOWENBERG EC ET AL. 2010. Severe malaria is associated with a deficiency of von Willebrand factor cleaving protease, ADAMTS13. Thromb Haemost 103: 181-187. 
MAdeIRA L, DEMARCo R, GAZARINI ML, VerJOVSKI-ALMEIDA S AND GARCIA CR. 2003. Human malaria parasites display a receptor for activated $\mathrm{C}$ kinase ortholog. Biochem Biophys Res Commun 306: 995-1001.

Maier AG, CoOKe BM, Cowman AF AND Tilley L. 2009. Malaria parasite proteins that remodel the host erythrocyte. Nat Rev Microbiol 7: 341-354.

MASON JC. 2003. Statins and their role in vascular protection. Clin Sci (Lond) 105: 251-266.

MAYOR A ET AL. 2011. Association of severe malaria outcomes with platelet-mediated clumping and adhesion to a novel host receptor. PLoS One 6: e19422.

MCCALLUM-DEIGHTON N AND HOLDER AA. 1992. The role of calcium in the invasion of human erythrocytes by Plasmodium falciparum. Mol Biochem Parasitol 50: 317-323.

MCCORMick CJ, Craig A, Roberts D, Newbold CI AND BERENDT AR. 1997. Intercellular adhesion molecule-1 and CD36 synergize to mediate adherence of Plasmodium falciparum-infected erythrocytes to cultured human microvascular endothelial cells. J Clin Invest 100: 2521-2529.

Mcmorran BJ, Marshall VM, De GraAF C, Drysdale KE, Shabbar M, SMyth GK, Corbin JE, ALEXANDER WS AND FoOTE SJ. 2009. Platelets kill intraerythrocytic malarial parasites and mediate survival to infection. Science 323: 797-800.

Mcrobert L, TAYlor CJ, Deng W, Fivelman QL, Cummings RM, Polley SD, Billker O AND BAKer DA. 2008. Gametogenesis in malaria parasites is mediated by the cGMP-dependent protein kinase. PLoS Biol 6: e139.

Mino N, Ishida T, KUWABA N, Ishida M, SHIMOTE-ABE K, TABUCHI K, OSHIMA T, YOSHIZUMI M AND CHAYAMA K. 2005. Role of the JNK pathway in thrombin-induced ICAM1 expression in endothelial cells. Cardiovasc Res 68: 289-298.

Muhia DK, Swales CA, Deng W, Kelly JM AND BaKer DA. 2001. The gametocyte-activating factor xanthurenic acid stimulates an increase in membrane-associated guanylyl cyclase activity in the human malaria parasite Plasmodium falciparum. Mol Microbiol 42: 553-560.

Muller S, Kammerbauer C, Simons U, Shibagaki N, Li LJ, Caughman SW and Degitz K. 1995. Transcriptional regulation of intercellular adhesion molecule-1: PMAinduction is mediated by NF kappa B. J Invest Dermatol 104: 970-975.

Mun EC, Mayol JM, Riegler M, O'Brien TC, FAROKHZAD OC, Song JC, Pothoulakis C, Hrnjez BJ AND MATTHEWS JB. 1998. Levamisole inhibits intestinal Cl- secretion via basolateral $\mathrm{K}+$ channel blockade. Gastroenterology 114: 1257-1267.

NDUNGU FM, SANNi L, URban B, STEPHENS R, NEWBOld CI, MARSH K AND LANGHORNE J. 2006. CD4 T cells from malaria-nonexposed individuals respond to the CD36Binding Domain of Plasmodium falciparum erythrocyte membrane protein-1 via an MHC class II-TCRindependent pathway. J Immunol 176: 5504-5512.
Newbold C, Warn P, Black G, Berendt A, Craig A, Snow B, Msobo M, Peshu N And Marsh K. 1997. Receptorspecific adhesion and clinical disease in Plasmodium falciparum. Am J Trop Med Hyg 57: 389-398.

Nicholson AC, Frieda S, Pearce A And Silverstein RL. 1995. Oxidized LDL binds to CD36 on human monocytederived macrophages and transfected cell lines. Evidence implicating the lipid moiety of the lipoprotein as the binding site. Arterioscler Thromb Vasc Biol 15: 269-275.

OCKenHouse CF, TANDON NN, MAGOWAN C, JAMIESON GA AND CHULAY JD. 1989. Identification of a platelet membrane glycoprotein as a falciparum malaria sequestration receptor. Science 243: 1469-1471.

Ockenhouse CF, Tegoshi T, MaEno Y, Benjamin C, Ho M, KAN KE, THWAY Y, Win K, AIKAWA M AND LOBB RR. 1992. Human vascular endothelial cell adhesion receptors for Plasmodium falciparum-infected erythrocytes: roles for endothelial leukocyte adhesion molecule 1 and vascular cell adhesion molecule 1. J Exp Med 176: 1183-1189.

OKAMOTO H, Yoshio T, KANEKO H AND YAMANAKA H. 2010. Inhibition of NF-kappaB signaling by fasudil as a potential therapeutic strategy for rheumatoid arthritis. Arthritis Rheum 62: 82-92.

ONO T ET AL. 2008. Adenylyl cyclase alpha and cAMP signaling mediate Plasmodium sporozoite apical regulated exocytosis and hepatocyte infection. PLoS Pathog 4: e1000008.

Pain A, Ferguson DJ, Kai O, URban BC, Lowe B, Marsh K AND RoBERTS DJ. 2001. Platelet-mediated clumping of Plasmodium falciparum-infected erythrocytes is a common adhesive phenotype and is associated with severe malaria. Proc Natl Acad Sci USA 98: 1805-1810.

PAPI A AND JOHNSTON SL. 1999. Rhinovirus infection induces expression of its own receptor intercellular adhesion molecule 1 (ICAM-1) via increased NF-kappaB-mediated transcription. J Biol Chem 274: 9707-9720.

PATTERSON RL, VAN ROSSUM DB, BARROW RK AND SNYDER SH. 2004. RACK1 binds to inositol 1,4,5-trisphosphate receptors and mediates $\mathrm{Ca} 2+$ release. Proc Natl Acad Sci USA 101: 2328-2332.

PINTO A, SORRENTINO RAND SORRENTINO L. 1990. Levamisole inhibits in vivo rat platelet aggregation by a release of prostacyclin-like factor. Gen Pharmacol 21: 255-259.

POBER JS. 2002. Endothelial activation: intracellular signaling pathways. Arthritis Res 4(Suppl 3): S109-116.

PodRez EA ET AL. 2002. Identification of a novel family of oxidized phospholipids that serve as ligands for the macrophage scavenger receptor CD36. J Biol Chem 277: 38503-38516.

RAABE AC, WENGELNIK K, BiLlKer O AND Vial HJ. 2011. Multipleroles for Plasmodium berghei phosphoinositidespecific phospholipase $\mathrm{C}$ in regulating gametocyte activation and differentiation. Cell Microbiol 13: 955-966.

Rahman A, Anwar KN, True Al and Malik AB. 1999. Thrombin-induced $\mathrm{p} 65$ homodimer binding to downstream NF-kappa B site of the promoter mediates endothelial ICAM-1 expression and neutrophil adhesion. J Immunol 162: 5466-5476. 
RANGACHARI K, DLUZEWSKI A, WILSON RJ AND GRATZER WB. 1986. Control of malarial invasion by phosphorylation of the host cell membrane cytoskeleton. Nature 324: 364-365.

Roberts DD, SHERWoOd JA, SPITALNIK SL, PANTON LJ, HOWARD RJ, DiXIT VM, FraZIER WA, MiLler LH AND GINSBURG V. 1985. Thrombospondin binds falciparum malaria parasitized erythrocytes and may mediate cytoadherence. Nature 318: 64-66.

Robles MS, Boyault C, KnUtTi D, PadmanabHan K AND WEITZ CJ. 2010. Identification of RACK1 and protein kinase Calpha as integral components of the mammalian circadian clock. Science 327: 463-466.

ROIKO MS AND CARRUTHERS VB. 2009. New roles for perforins and proteases in apicomplexan egress. Cell Microbiol 11: 1444-1452.

Romano M, Mezzetti A, Marulli C, Ciabattoni G, Febo F, Di IEnNo S, Roccaforte S, Vigneri S, Nubile G, Milani M AND DAVI G. 2000. Fluvastatin reduces soluble P-selectin and ICAM-1 levels in hypercholesterolemic patients: role of nitric oxide. J Investig Med 48: 183-189.

Rowe JA, ClAESSENS A, CORRIGAN RA AND ARMAN M. 2009. Adhesion of Plasmodium falciparum-infected erythrocytes to human cells: molecular mechanisms and therapeutic implications. Expert Rev Mol Med 11: e16.

Russo I, BABbitT S, MURALIDHARAN V, BUtLER T, OKSMAN A AND GoldBerg DE. 2010. Plasmepsin V licenses Plasmodium proteins for export into the host erythrocyte. Nature 463: 632-636.

Russo I, OKSMAN A, VAuPEl B AND GOLDBERG DE. 2009. A calpain unique to alveolates is essential in Plasmodium falciparum and its knockdown reveals an involvement in pre-S-phase development. Proc Natl Acad Sci USA 106: 1554-1559.

SARTORELLO R, AMAYA MJ, NATHANSON MH AND GARCIA CR. 2009. The plasmodium receptor for activated $C$ kinase protein inhibits $\mathrm{Ca}(2+)$ signaling in mammalian cells. Biochem Biophys Res Commun 389: 586-592.

SATTERLEE JS AND SUSSMAN MR. 1998. Unusual membraneassociated protein kinases in higher plants. J Membr Biol 164: 205-213.

SCHECHTMAN D AND MOCHLY-RoSEN D. 2001. Adaptor proteins in protein kinase C-mediated signal transduction. Oncogene 20: 6339-6347.

Schofield L, Novakovic S, Gerold P, Schwarz RT, MCCONVILle MJ AND TACHADO SD. 1996. Glycosylphosphatidylinositol toxin of Plasmodium upregulates intercellular adhesion molecule-1, vascular cell adhesion molecule-1, and E-selectin expression in vascular endothelial cells and increases leukocyte and parasite cytoadherence via tyrosine kinase-dependent signal transduction. J Immunol 156: 1886-1896.

SICARD A ET AL. 2011. Activation of a PAK-MEK signaling pathway in malaria parasite-infected erythrocytes. Cell Microbiol 13: 836-845.
SILVERSTEIN RL, BAIRD M, LO SK AND YESNER LM. 1992. Sense and antisense cDNA transfection of CD36 (glycoprotein IV) in melanoma cells. Role of CD36 as a thrombospondin receptor. J Biol Chem 267: 16607-16612.

SINGH S, ALAM MM, PAL-BHOWMICK I, BRZOSTOWSKI JA AND ChITNIS CE. 2010. Distinct external signals trigger sequential release of apical organelles during erythrocyte invasion by malaria parasites. PLoS Pathog 6: e1000746.

SNOW RW, GUERRA CA, NOOR AM, MYINT HY AND HAY SI. 2005. The global distribution of clinical episodes of Plasmodium falciparum malaria. Nature 434: 214-217.

SRIVASTAVAKETAL. 2008. Platelet factor 4 mediates inflammation in experimental cerebral malaria. Cell Host Microbe 4: $179-187$.

TACHADO SD, GEROLD P, MCCONVILLE MJ, BALDWIN T, QUILICI D, Schwarz RT AND SCHOFIELD L. 1996. Glycosylphosphatidylinositol toxin of Plasmodium induces nitric oxide synthase expression in macrophages and vascular endothelial cells by a protein tyrosine kinase-dependent and protein kinase C-dependent signaling pathway. J Immunol 156: 1897-1907.

Tachado SD, Gerold P, Schwarz R, NovaKovic S, MCCONVILle M AND SCHOFIELD L. 1997. Signal transduction in macrophages by glycosylphosphatidylinositols of Plasmodium, Trypanosoma, and Leishmania: activation of protein tyrosine kinases and protein kinase $\mathrm{C}$ by inositolglycan and diacylglycerol moieties. Proc Natl Acad Sci USA 94: 4022-4027.

TANDON NN, KRALISZUAND JAMIESON GA. 1989. Identification of glycoprotein IV (CD36) as a primary receptor for platelet-collagen adhesion. J Biol Chem 264: 7576-7583.

TAOUfiQ Z, Gay F, BALVANyos J, Ciceron L, TeFit M, LECHAT P AND MAZIER D. 2008. Rho kinase inhibition in severe malaria: thwarting parasite-induced collateral damage to endothelia. J Infect Dis 197: 1062-1073.

TAOUfiQ Z, Pino P, N'Dilimabaka N, Arrouss I, Assi S, Soubrier F, REBollo A AND MAZIER D. 2011. Atorvastatin prevents Plasmodium falciparum cytoadherence and endothelial damage. Malar J 10: 52.

TAYLOR HM, MCROBERT L, GRAINGER M, SICARD A, DLUZEWSKI AR, Hopp CS, Holder AA AND BAKER DA. 2010. The malaria parasite cyclic GMP-dependent protein kinase plays a central role in blood-stage schizogony. Eukaryot Cell 9: 37-45.

Treutiger CJ, Heddini A, Fernandez V, Muller WA AND WAHLGREN M. 1997. PECAM-1/CD31, an endothelial receptor for binding Plasmodium falciparum-infected erythrocytes. Nat Med 3: 1405-1408.

Tripathi AK, Sha W, ShUlaEV V, Stins MF and Sullivan JR DJ. 2009. Plasmodium falciparum-infected erythrocytes induce NF-kappaB regulated inflammatory pathways in human cerebral endothelium. Blood 114: 4243-4252.

TRIPATHI AK, SUlLIVAN DJ AND STINS MF. 2006. Plasmodium falciparum-infected erythrocytes increase intercellular adhesion molecule 1 expression on brain endothelium through NF-kappaB. Infect Immun 74: 3262-3270. 
TURNER GD ET AL. 1994. An immunohistochemical study of the pathology of fatal malaria. Evidence for widespread endothelial activation and a potential role for intercellular adhesion molecule-1 in cerebral sequestration. Am J Pathol 145: 1057-1069.

UDOMSANGPETCH R, REINHARDT PH, SCHOLLAARDT T, ELLIOTT JF, KuBES P AND Ho M. 1997. Promiscuity of clinical Plasmodium falciparum isolates for multiple adhesion molecules under flow conditions. J Immunol 158: 4358-4364.

Urban BC, Ferguson DJ, PAin A, Willcox N, Plebanski M, AUSTYN JM AND ROBERTS DJ. 1999. Plasmodium falciparum-infected erythrocytes modulate the maturation of dendritic cells. Nature 400: 73-77.

VAID A, RANJAN R, SMYThe WA, Hoppe HC AND SHARM P. 2010. PfPI3K, a phosphatidylinositol-3 kinase from Plasmodium falciparum, is exported to the host erythrocyte and is involved in hemoglobin trafficking. Blood 115: 2500-2507.

VAID A AND SHARMA P. 2006. PfPKB, a protein kinase B-like enzyme from Plasmodium falciparum: II. Identification of calcium/calmodulin as its upstream activator and dissection of a novel signaling pathway. J Biol Chem 281: 27126-27133.

VAID A, Thomas DC AND Sharma P. 2008. Role of Ca2+/ calmodulin-PfPKB signaling pathway in erythrocyte invasion by Plasmodium falciparum. J Biol Chem 283: 5589-5597.

VANHAESEBROECK B AND ALESSI DR. 2000. The PI3K-PDK1 connection: more than just a road to PKB. Biochem J 346 (Pt 3): 561-576.

VIEBIG NK, WULBRAND U, FORSTER R, ANDREWS KT, LANZER M AND KNOLLE PA. 2005. Direct activation of human endothelial cells by Plasmodium falciparum-infected erythrocytes. Infect Immun 73: 3271-3277.

VOGETSEDER W AND DIERICH MP. 1991. Intercellular adhesion molecule-1 (ICAM-1, CD 54) is associated with actinfilaments. Immunobiology 182: 143-151.

WAKNINE-GRINBERG JH, MCQUILLAN JA, HunT N, GINSBURG H AND GOLENSER J. 2010. Modulation of cerebral malaria by fasudil and other immune-modifying compounds. Exp Parasitol 125: 141-146.

WANG Q, PfeIfFer GR 2ND, SteVEns T AND DOERSChUK CM. 2002. Lung microvascular and arterial endothelial cells differ in their responses to intercellular adhesion molecule-1 ligation. Am J Respir Crit Care Med 166: 872-877.

WARd P, Equinet L, PACKer J AND Doerig C. 2004. Protein kinases of the human malaria parasite Plasmodium falciparum: the kinome of a divergent eukaryote. BMC Genomics 5: 79.

WASSMER SC, COMBES V, CANDAL FJ, JUHAN-VAGUE I AND GRAU GE. 2006a. Platelets potentiate brain endothelial alterations induced by Plasmodium falciparum. Infect Immun 74: 645-653.

Wassmer SC, De Souza JB, Frere C, CANDAl FJ, JuhanVAGUE I AND GRAU GE. 2006b. TGF-betal released from activated platelets can induce TNF-stimulated human brain endothelium apoptosis: a new mechanism for microvascular lesion during cerebral malaria. J Immunol 176: 1180-1184.
Wassmer SC, Lepolard C, Traore B, Pouvelle B, Gysin J AND GRAU GE. 2004. Platelets reorient Plasmodium falciparum-infected erythrocyte cytoadhesion to activated endothelial cells. J Infect Dis 189: 180-189.

Wassmer SC, Taylor T, Maclennan CA, Kanjala M, Mukaka M, MolyneuX ME and GraU GE. 2008. Platelet-induced clumping of Plasmodium falciparuminfected erythrocytes from Malawian patients with cerebral malaria-possible modulation in vivo by thrombocytopenia. J Infect Dis 197: 72-78.

Wolfrum S, JENSEN KS AND LIAO JK. 2003. Endotheliumdependent effects of statins. Arterioscler Thromb Vasc Biol 23: 729-736.

Wu Y, WANG X, LiU X AND Wang Y. 2003. Data-mining approaches reveal hidden families of proteases in the genome of malaria parasite. Genome Res 13: 601-616.

Wurtz N, ChAPUS C, DESPLANS J AND PARZY D. 2011. cAMPdependent protein kinase from Plasmodium falciparum: an update. Parasitology 138: 1-25.

Wurtz N, Desplans J AND PARZY D. 2009. Phenotypic and transcriptomic analyses of Plasmodium falciparum protein kinase A catalytic subunit inhibition. Parasitol Res 105: 1691-1699.

WYKES MNAND GOOD MF. 2008. What really happens to dendritic cells during malaria? Nat Rev Microbiol 6: 864-870.

Xue J, Thippegowda PB, Hu G, BACHMAiER K, Christman JW, MALIK AB AND TiRUPPATHI C. 2009. NF-kappaB regulates thrombin-induced ICAM-1 gene expression in cooperation with NFAT by binding to the intronic NF-kappaB site in the ICAM-1 gene. Physiol Genomics 38: 42-53.

YiPp BG, BARUCH DI, BRADY C, MURRAY AG, LOOAREESUWAN S, KUBES P AND Ho M. 2003a. Recombinant PfEMP1 peptide inhibits and reverses cytoadherence of clinical Plasmodium falciparum isolates in vivo. Blood 101: 331-337.

YIPP BG, ROBBINS SM, RESEK ME, BARUCH DI, LOOAREESUWAN S AND HO M. 2003b. Src-family kinase signaling modulates the adhesion of Plasmodium falciparum on human microvascular endothelium under flow. Blood 101: 2850-2857.

YUAN J ET AL. Chemical genomic profiling for antimalarial therapies, response signatures, and molecular targets. Science 333: 724-729.

ZANG-Edou ES, Bisvigou U, TAOUfiQZ, LeKoulou F, LeKANADouki JB, Traore Y, MaZier D AND TOURE-Ndouo FS. 2010. Inhibition of Plasmodium falciparum field isolatesmediated endothelial cell apoptosis by Fasudil: therapeutic implications for severe malaria. PLoS One 5: e13221.

ZHOU Q AND LIAO JK. 2009. Statins and cardiovascular diseases: from cholesterol lowering to pleiotropy. Curr Pharm Des 15: 467-478. 